\title{
SEJARAH QIRA'AT IMAM 'ASHIM DI NUSANTARA
}

\author{
Fathul Amin,
}

\author{
Sekolah Tinggi Ilmu Tarbiyah Makhdum Ibrahim Tuban, \\ email : fathulamin@stitmatuban.ac.id
}

\begin{abstract}
Abstrak
Artikel ini membahas tentang Sejarah Qira'at di Nusantara. Tujuan dari penulisan artikel ini adalah untuk mengetahui sejarah qiro'at yang digunakan di Nusantara. Jenis penelitian ini adalah penelitian kualitatif. Metode yang dipakai dalam penelitian ini adalah library research dan studi observasi. Analisa data dengan cara induktif dan mengacu pada temuan di lapangan. Teori yang dipakai untuk menyelesaikan rumusan masalah adalah teori sanad Qira'at itu sendiri, yaitu masuknya madzhab qira'at Ashim Riwayat Hafsh di Nusantara. Hasil dari penelitian adalah Perkembangan madzhab qira'at 'Ashim riwayat Hafsh secara definitif di bumi Nusantara baru dimulai pada abad ke-20. Bacaan al-Qur'an penduduk Nusantara sejak masa awal datangnya Islam bisa di pastikan berafiliasi pada madzhab qira'at 'Ashim riwayat Hafsh. Hal ini bisa dibuktikan melalui beberapa kesamaan qawa'id ushuliyyah maupun farsy al-huruf qira'at al-Qur'an penduduk Nusantara dengan teori-teori qira'at yang terdapat dalam madzhab qira' at 'Ashim riwayat Hafsh.
\end{abstract}

Kata kunci : Riwayat Hafsh, Qiro’at Imam ‘Ashim.

\section{PENDAHULUAN}

Al-Qur'an merupakan kitab suci yang sarat akan keberagaman bahasa yang terdapat di dalamnya. Seperti halnya telah disinggung dalam hadist Nabi sendiri. Keberagaman yang terkandung dalam model bacaan al-Qur'an sebagai salah satu cara pilihan yang dapat mempermudah umat Islam di seluruh penjuru dunia.

Hal ini amatlah diperhatikan oleh Nabi Muhammad ketika menerima wahyu dari Jibril, beliau meminta adanya pilihan gaya baca. Tentu saja karena beliau telah mempertimbangkan al-Qur'an tidak hanya akan turun pada satu lingkup wilayah yang hanya memiliki satu logat bahasa, namun alQur'an adalah pengiring agama Islam yang rahmatal lil 'alamin.

Sebagaimana yang telah kita ketahui bahwa gaya baca al-Qur'an atau Qira'at terbagai menjadi beberapa macam yang telah di bukukan dan dianggap sah dan shohih sanadnya. Diterima tidaknya Qira'at dapat diketahui dari berbagai unsur yang mengitarinya. Seperti yang telah diketahui bahwasanya ketika hendak membahas mengenai Qiro'at yang ada di Nusantara, baik penulis maupun pembaca tidak dapat mengesampingkan sejarah masuknya Islam dan pembelajarannya di Nusantara serta Qiro'at yang sangat populer yang ada di Nusantara.

Dalam kesempatan ini penulis akan sedikit menyinggung pembahasan mengenai salah satu cara qiraat yang terdapat di Nusantara. Mengenai topik tersebut tentu saja banyak hal yang tidak dapat di kesampingkan dalam mengurai beberapa point penting yang mengitarinya, seperti halnya sejarah 
masuknya Qiro'at di Nusantara itu sendiri, tokoh-tokoh pendukung yang berperan dalam membawa sanad Qiro'at serta pengajarannya di Nusantara.

Sebelum mengenal lebih jauh perkembangan Qira'at yang ada di Nusantara, mula-mula harus diketahui masuknya Islam dan penyebaran Islam di Nusantara seperti yang tertuang dalam buku Sejarah Al-Qur'an karya Abu bakar Aceh yang mana telah ia tuturkan bahwa Islam masuk melalui para pedagang Arab, Persia dan India yang kemudian menikah dengan orang Nusantara berjangka waktu selama abad ke-7 M sampai dengan abad ke 15. Setelah Islam masuk ke dalam Nusantara melewati perdagangan dan mereka mulai mengajarkan sedikit demi sedikit mengenai pelajaran terkait dengan al-Qur'an. Wawan Djunaedi juga menuturkan bahwa pada masa itu baik pedagang Arab dan India, musafir dari Persia sangat mempengaruhi penyebaran Islam beserta pengajaran alQur'an (keragaman qira'at) yang mereka ajarkan kepada masyarakat Nusantara.

Dalam hal ini Abu Bakar Atjeh membagi metode pengajaran al-Qur'an di Nusantara atas dua macam: pertama, diberikan di rumah atau langgar. Proses pengajaran dilakukan dengan Guru membaca dan murid menuruti bacaan gurunya itu sambil melihat dan menunjuk kepada huruf-huruf hijaiyah yang dibacanya itu. Sesudah beberapa kali dan beberapa lama murid-murid membaca pelajarannya, masing-masing membaca pelajarannya sendiri- sendiri, sehingga suaranya kadangkadang menggemparkan langgar itu, maka kemudian datanglah seorang kepada gurunya atau pembantu gurunya, untuk didengarkan bacaannya. demikianlah berturut-turut sampai murid-murid pandai membaca al-Qur'an. Kedua, di berikan dipesantren atau madrasah. Dapat juga disebutkan disini, beberapa guru al-Qur'an yang besar jasanya dibeberapa wilayah yang ada di Nusantara, seperti: Hasannudin, Pangeran Jambu Karang, Sunan Geseng, Sunan Tembayat, Sunan Ngunjung, Sunan Panggung, Syekh Abdul Muhji dll. Beberapa ulama ini merupakan pembuka sistem pengajaran al-Qur'an pada masa awal sebelum qira'at dipelajari secara mendalam. Demikian dua metode ini menjadi salah satu bukti bahwa Islam masuk ke Nusantara berhubungan erat dengan penyebaran al-Qur'an (keragaman qira'at) di Nusantara.

\section{METODE PENELITIAN}

Adapun metode penelitian kajian pustaka atau studi kepustakaan yaitu berisi teori teori yang relevan dengan masalah-masalah penelitian. Adapun masalah pada penelitian ini adalah untuk mengetahui “Sejarah Qiro'at Al-Qur'an di Nusantara.” Pada bagian ini dilakukan pengkajian mengenai qiro'at Al-Qur'an yang berkembang di Indonesia berdasarkan literatur yang tersedia, terutama dari artikel-artikel yang dipublikasikan dalam berbagai jurnal ilmiah. Kajian pustaka berfungsi untuk membangun konsep atau teori yang menjadi dasar studi dalam penelitian. Kajian pustaka atau studi pustaka merupakan kegiatan yang diwajibkan dalam penelitian, khususnya 
penelitian akademik yang tujuan utamanya adalah mengembangkan aspek teoritis maupun aspek manfaat praktis. Sehingga dengan menggunakan metode penelitian ini penulis dapat dengan mudah menyelesaikan masalah yang hendak diteliti.

\section{HASIL DAN PEMBAHASAN}

\section{Sejarah Masuknya Islam di Nusantara}

Sebelum mengenal lebih jauh perkembangan Qira'at yang ada di Nusantara, mula-mula harus diketahui masuknya Islam dan penyebaran Islam di Nusantara seperti yang tertuang dalam buku Sejarah Al-Qur'an karya Abu bakar Aceh yang mana telah ia tuturkan bahwa Islam masuk melalui para pedagang Arab, Persia dan India yang kemudian menikah dengan orang Nusantara berjangka waktu selama abad ke-7 M sampai dengan abad ke 15. Setelah Islam masuk ke dalam Nusantara melewati perdagangan dan mereka mulai mengajarkan sedikit demi sedikit mengenai pelajaran terkait dengan al-Qur'an. Wawan Djunaedi juga menuturkan bahwa pada masa itu baik pedagang Arab dan India, musafir dari Persia sangat mempengaruhi penyebaran Islam beserta pengajaran al-Qur'an (keragaman qira'at) yang mereka ajarkan kepada masyarakat Nusantara.

Dalam hal ini Abu Bakar Atjeh membagi metode pengajaran al-Qur'an di Nusantara atas dua macam: pertama, diberikan di rumah atau langgar. Proses pengajaran dilakukan dengan Guru membaca dan murid menuruti bacaan gurunya itu sambil melihat dan menunjuk kepada huruf-huruf hijaiyah yang dibacanya itu. Sesudah beberapa kali dan beberapa lama murid-murid membaca pelajarannya, masing-masing membaca pelajarannya sendiri- sendiri, sehingga suaranya kadang-kadang menggemparkan langgar itu, maka kemudian datanglah seorang kepada gurunya atau pembantu gurunya, untuk didengarkan bacaannya. demikianlah berturutturut sampai murid-murid pandai membaca al-Qur'an. Kedua, di berikan dipesantren atau madrasah. Dapat juga disebutkan disini, beberapa guru al-Qur'an yang besar jasanya dibeberapa wilayah yang ada di Nusantara, seperti: Hasannudin, Pangeran Jambu Karang, Sunan Geseng, Sunan Tembayat, Sunan Ngunjung, Sunan Panggung, Syekh Abdul Muhji dll. Beberapa ulama ini merupakan pembuka sistem pengajaran al-Qur'an pada masa awal sebelum qira'at dipelajari secara mendalam. Demikian dua metode ini menjadi salah satu bukti bahwa Islam masuk ke Nusantara berhubungan erat dengan penyebaran al-Qur'an (keragaman qira'at) di Nusantara.

Ilmuqira'at adalah disiplin ilmu yang memiliki otoritas tertinggi dalam menentukan autentisitas sumber utama ajaran Islam (al-Qur'an). Tanpa merujuk pada standar yang ditentukan disiplin ilmu ini, maka sumber utama ajaran Islam tidak mungkin bisa dipertanggung 
jawabkan secara ilmiah. Didalam ilmu qira'at terdapat standar dan kualifikasi yang ditetapkan dalam memilih secara tegas antara riwayat qira'at yang absah dan tidak absah.

Eksistensi dari ilmu qira'at memang tidak begitu populer di kalangan kaum muslim. Masyarakat muslim lebih akrab dengan ilmu tajwid sebagai ilmu yang berkaitan dengan hukum bacaan lafal al-Qur'an, ketimbang ilmu qira'at. Jadi tidak heran kalau individu masyarakat muslim khususnya Nusantara banyak yang tidak mengetahui madzahab qira'at al-Qur'an yang dibaca sehari-hari. Di dalam ilmu qira'at terdapat beberapa imam yang membawahi madzhab qira'at diantaranya: qira'at 'Ashim, qira'at Hamzah, atau qira'at Nafi'.

\section{Sejarah Qira'at Nusantara}

Qira'at Imam 'Ashim riwayat Hafsh menjadi madzhab qira' at yang dibaca oleh mayoritas umat muslim di dunia, lebih khususnya lagi penduduk di Nusantara. Maka dari itu pengkajian bagaimana akar historis perkembangan qira'at 'Ashim riwayat Hafsh perlu dilakukan untuk mengetahui argumentasi intelektual hakikat madzhab qira'at 'Ashim riwayat Hafsh yang menjadi bacaan al-Qur'an masyarakat sehari-hari. Setelah mengetahui kaum muslimin akan menyadari bahwa madzhab qira'at 'Ashim riwayat Hafsh bukan satu-satunya madzhab qira'at yang benar. Dengan demikian, kaum muslim Indonesia tidak akan mudah menyalahkan orang lain qira'atnya tidak sama dengan qira'at yang dibaca sehari-hari.

Maka disini akan dibahas pembahasan tentang kesejarahan masuk dan berkembangnya madzhab 'Ashim riwayat Hafsh di kawasan Nusantara yang merupakan hasil resume dari buku Wawan Djunaedi “ Sejarah Qira'at al-Qur'an di Nusantara”. Pembahasan akan dimulai dari: pertama, sejarah awal masuknya qira'at Nusantara secara de facto (Ulama-ulama pembawa madzhab qira'at, para qari terkenal di Nusantara, kurikulum yang digunakan di Nusantara, dan kitab tajwid yang corak dan afiliasinya terhadap beberapa madzhab qira'at yang ada) dan secara de yure (Dimulai pada abad ke-20 dibawa oleh KH. Moenawwir dan KH. Munawwar). Kedua, pembahasan Qira'at 'Ashim riwayat Hafsh: sosok dan teori qira'at.

\section{Masuknya Madzhab Qira'at Ashim Riwayat Hafsh di Nusantara}

Untuk melacak akar perkembangan qira'at Ashim di Nusantara maka dapat melalui pendekatan secara de facto dan de yure.

\section{1. “De Facto" Qira'at “Ashim riwayat Hafsh di Nusantara}

Bukti sejarah hadirnya qira'at 'Ashim riwayat Hafsh di Nusantara, dilihat dari beberapa aspek, diantaranya sebagai berikut:

a. Ulama Pembawa Madzhab Qira'at Ashim di Nusantara 
Seorang agamawan dan pengembara dari Cina bernama I-Tsing memberi informasi bahwa masa awal kedatangan Islam ke Nusantara terjadi pada tahun 51/671. Ia telah menumpang kapal milik pedagang muslim Timur Tengah yang kebanyakan berasal dari Arab dan Persia. Selanjutnya ia menginformasikan bahwa hubungan Timur Tengah dan Timur jauh sudah berlangsung sejak lama. Menurut penulis kronik asal Cina, Chou Ch'u-fei, kawasan yang menjadi penghubung antara kedua kawasan tersebut adalah Sriwijaya. Pelabuhan Sriwijaya menjadi export terpenting antara kawasan Timur Tengah dan Timur Jauh.Orang-orang muslim Arab, Persia dan India telah mengadakan kontak dagang dengan komunitas Nusantara pada abad 7-8 M hingga abad-abad berikutnya.

Jika pada masa awal-awal kaum muslimin Arab dan Persia yang singgah ke Nusantara lebih memfokuskan pada sektor ekonomi, maka pada abad ke-12 para pengembara sufi ikut menumpang kapal-kapal dagang mereka untuk melakukan penyebaran Islam secara aktif di Nusantara.

Selanjutnya jika menyinggung pendapat yang menyebut bahwa saudagar Persia dianggap memiliki andil dalam dalam menyebarluaskan Islam di kawasan Nusantara, maka perlu diketahui latar belakang penaklukan Persia melalui pertempuran di Qasadiyah dan Mada'in pada masa khalifah Umar bin Khattab tahun 17/637. Sejak peristiwa itu orangorang Persia secara massal memeluk agama Islam. Kawasan Kufah yang secara geografis memiliki posisi yang dekat dengan Qasadiyah dan Mada'in, sehingga orang-orang mu'alaf Persia belajar agama Islam dari para ulama Kufah. Itu artinya kemungkinan orang-orang Persia dimungkinkan belajar cara baca al-Qur'an sesuai dengan ragam qira'at penduduk Kufah yang sebagian besar menganut qira'at sahabat Abdullah bin Mas'ud yang tidak lain kakek guru Imam Ashim.Dan selanjutnya orang-orang Persia melakukan perjalanan ke kawasan timur dan mengajarkan ragam bacaan qira'at kepada penduduk Nusantara.

Sedangkan pendapat yang menyebut bahwa Islam di Nusantara berasal dari India tidak memiliki cukup bukti untuk menganggap orang muslim India sebagai pembawa madzhab qira'at Ashim riwayat Hafsh di Nusantara. Hal ini dikarenakan ekspansi yang dilakukan oleh Muhammad Ibn al-Qasim al-Tsaqafi sebagai panglima perang yang bermarkas di Damaskus tidak memiliki pengaruh cukup kuat untuk mewarnai bacaan qira'at penduduk setempat. Jadi kemungkinan pengaruh qira'at Ashim yang dibawa oleh orangorang Persia ke kawasan India lebih dominan dibanding pengaruh qira'at para prajurit perang Damaskus.

Selajutnya ketiga komponen pembawa Islam yang berasal dari Arab, Persia maupun India sama-sama memiliki kemungkinan memberi pengaruh jenis qira'at kepada penduduk 
Nusantara. Namun dengan mempertimbangkan letak geografis Persia yang lebih dekat dengan kawasan Kufah sebagai tempat lahirnya qira'at Ashim, maka orang orang-orang Persia dianggap memiliki ruang lebih besar sebagai ulama-ulama yang membawa qira'at Ashim riwayat Hafsh di wilayah Nusantara.

b. Para Qari Terkenal di Nusantara

Salah satu tokoh qari' pada masa awal sejarah Islam Nusantara hidup pada abad ke14 yaitu ulama Jawa Tengah bernama Maulana Husain yang datang ke Maluku yang dikabarkan mendemostrasikan kemahirannya dalam menulis huruf Arab dan membaca alQur'an dengan irama yang sangat indah hingga penduduk setempat tergerak untuk mempelajari al-Qur'an. Menurut Arnold, Husain merupakan salah satu pedagang pendakwah agama Islam yang mendemostrasikan tilawah al-Qur'an kepada masyarakat setempat.

Ulama qari'nusantara lain dalam sejarah Nusantara adalah Syaikh Abdurrahman yang mendirikan surau besar mirip pesatren yang ada di Batuhampar, Payakumbuh, dan Jawa. Pada akhir abad ke-18 Syaikh Abdurrahman ini tidak hanya mengajarkan cara baca alQur'an dengan baik dan benar, namun juga mengajarkan tilawah al-Qur'an dengan irama.

Namun jika merujuk terminologi yang digunakan dalam disiplin ilmu qira'at dimana seorang muqri' yaitu seorang yang alim dalam bidang qira'at dan telah menerima ijazah qira'at serta telah diberi kewenangan untuk memberikan sanad qira'atnya kepada orang lain, maka kedua tokoh yang telah disebut belum memenuhi kriteria tersebut.

Selanjutnya berdasarkan dokumentasi sejarah pada akhir abad ke-20 ditemukan bukti fisik berupa sanad qira'at milik KH. Moenawir dari Yogyakarta dan KH. Munawar dari Gresik yang sanadnya mutawatir sampai kepada Rasulullah. Kedua tokoh ilmu qira'at inilah yang menyumbangkan disiplin ilmu qira'at di Nusantara yang sesuai dengan pengertian istilah muqri' dalam ilmu qira'at.

c. Kurikulum Pendidikan Islam di Nusantara

Pada tahap paling awal para ulama pembawa ajaran Islam hanya sebatas menyampaikan pesan religius yang terkandung dalam firman-firman Allah SWT. Namun pada tahap berikutnya, para ulama mengajarkan cara baca al-Qur'an kepada para mu'allaf dari penduduk bumi. Di antara mata pelajaran yang memiliki hubungan erat dengan disiplin ilmu qira'at dalam pendidikan Islam di Nusantara adalah pelajaran cara membaca al-Qur'an dan ilmu tajwid. Kedua pelajaran inilah yang menunjang perkembangan madzhab qira'at Ashim riwayat Hafsh di Nusantara. 
Salah satu buku yang dijadikan rujukan dalam pedoman pelajaran membaca huruf Hija'iyyah di Minangkabau adalah buku Qa'idah Baghdadiyyah (artinya: kaidah Baghdad), maka metode pembelajaran al-Qur'an tersebut diadopsi dariBaghdad yang sebagian besar menganut madzhab qira'at Ashim riwayat Hafsh. Oleh karena itu, sistem pembelajaran alQur'an yang diterapkan di Nusantara sesuai dengan madzhab qira'at dan metodologi yang diterapkan di negeri asal para ulama pembawanya yaitu Baghdad.

Selain itu dari beberapa kurikulum pendidikan Islam yang ada di Nusantara ditemukan susunan kurikulum pendidikan Islam yang memuat materi-materi terkait madzhab qira'at misalnya ilmu tajwid, seperti; (1) Kurikulum pendidikan di Pondok Pesantren Tambak Beras Jombang pada tahun 1959 yang mengacu pada kitab tajwid Hidayah al-Shibyan dan Tuhfah al-Athfal,(2) Kurikulum pendidikan Madrasah Mamba'ul Ulum Surakarta pada tahun 1916, mengajarkan dua macam kitab tajwid, yaitu Tuhfah alAthfal dan Jazariyah(3) Kurikulum Madrasah Perikatan Umat Islam (PUI) pada tahun 1955 mengajarkan kitab tajwid Faturrahman fi Tajwid al-Qur'an.(4) Kitab tajwid yang diajarkan pada jenjang Sekolah Guru adalah kitab Hidayah al-Mustafid fi Ahkam al-Tajwid.Adapun pembahasan mengenai kitab-kitab tersebut akan dijelaskan pada pembahasan selanjutnya.

d. Kitab Tajwid pada Kurikulum Pendidikan Awal di Nusantara

Salah satu bentuk materi yang dituju untuk menunjang penelusuran qira'at madzhab 'Ashim riwayat Hafsh adalah kitab-kitab tajwid yang berkembang di Nusantara. Di antaranya adalah sebagai berikut:

1) Hidayah al Mustafidl fi 'Ilm al Tajwid

Kitab Hidayah al Mustafidl fi 'Ilm al Tajwidmerupakan sebuah karya Abu Rimah. Naskah kitab beliau di terbitkan Maktabah Al-Syaikh Salim bin Sa'ad bin NabhanSurabaya. Kitab tersebut juga sudah dialihbahasakan dalam bahasa Madura oleh Kiai Raden 'Abd al Majid Tamim.

Kitab ini ditulis memang secara khusus membahas mengenai ilmu tajwid yang bermdzhab qira' at 'Ashim riwayata Hafsh. Hal ini dilihat dalam muqaddimah beliau yang menyebutkan secara jelas bahwa beliau menulis berdasarkan riwayat 'Ashim dari Hafsh. Nuansa ini dikuatkan lagi dengan penyebutan Muhammad Mahmud al Najjar mengenai sub bahasan yang paling khas dari qira'at yakni mengenai saktah yang terdapat dalam riwayat Hafsh.

2) Fathurrahman fii Tajwid al Qur'an

Kitab ini ditulis oleh Sa'id bin Sa'ad bin Nabhan.Dalam Mukaddimah memang tidak disebutkan secara ekplisit mengenai qira' at 'Ashim riwayat Hafsh, namun ketika ditelaah 
secara detail maka ada kalimat-kalimat tertentu yang berindikasi pada madzhab qira'at 'Ashim riwayat Hafsh. Hal ini diketahui pada redaksi halaman 9 dimana beliau memasukkan pembahasan saktah qira'at riwayah 'Ashim riwayat Hafsh padahal temanya berkaitan tentang kesepakatan ulama mengenai idgham.

3) Hidayah al-Shibyan fi Tajwid al-Qur'an

Kitab tajwid Hidayah al-Shibyan fi Tajwid al-Qur'an disusun oleh Sa'id bin Sa'ad bin Nabhan yang tidak lain penyusun kitab Fathurrahan fi Tajwid al-Qur'an yan telah dibahas sebelumnya. Naskah kitab ini dicetak bersamaan dengan terjemahan bahasa Jawa oleh KH. Ahmad Shiddiq - Jember, yakni terdapat dalam satu jilid dengan kitab Fathurrahan fi Tajwid al-Qur'an yang telah diterbitkan Maktabah al-Syaikh Salim bin Sa'ad Nabhan - Surabaya.Sa'id bin Sa'ad bin Nabhan menyajikan materi-materi tajwid yang bersifat elementer dan sangat simpel. Itulah sebabnya Sa'id bin Sa'ad bin Nabhan tidak mengangkat teori-teori tajwid sifatnya yang terlalu detail, sehingga akan membebani daya kognitif anak-anak.

4) Tuhfah al-Athfal

Kitab ini dikarang oleh Sulaiman bin Husain bin Muhammad al-Jamzuriy (w.1198/1784) yang juga masyhur dengan panggilan Afandi. Beliau meruakan ulama yang terbilang produktif dalam menulis karya ilmiah. Beliau tidak menyebutkan bahwa kitabnya berdasarkan madzhab qira'at tertentu tapi beliau mengakui bahwa mendapat pembelajaran dari gurunya yakni Syaikh al Mihiy. Syaikh al Mihiy sendiri merupakan seorang tunanetra yang lahir di Mih daerah Qura manuf (Mesir) beliau adalah ulama ahli shufi yang bermadzhab Syafi'i dan ahli bidang qira'at. Beliau wafat tahun 1204/1795. 'Ali al Mihiy sendiri merupakan ayahanda dari ulama besar ahli qira'at yakni Musthofa Al Mihiy. Dari sini, penulis dapat menyimpulkan bahwa kitab ini ditransmisikan oleh sanad yang berbau qira'at 'Ashim riwayat Hafsh.

5) Matn al Jazariyyah

Kitab Matn al Jazariyah ditulis oleh Abu al Khait Syamsuddin Muhammad bin Muhammad bin Muhammad al Jazariy (751-833/1350-1429). Kitab ini disusun dengan model Nadhm yang berjumlah sebanyak 107 bait syair. Di dalam kitabnya, Ibnu AL Jazariy tidak menyebutkan secara ekplisit bahwa kitab tajwidnya berdasarkan madzhab qiraat tertentu. Namun, yang jelas adalah kitab nadhm ini lebih komplek daripada kitab nadhm lainnya.

Dari uraian tersebut dapat disimpulkan bahwa, ada tiga kategori jenis kitab tajwid yang ada di Nusantara, yaitu: Pertama, Kitab yang secara ekplisit beafiliasi memberikan 
keterangan bahwa bermadzhab qira'at 'Ashim riwayat Hafsh, kitab yang tergolong ini Kitab Hidayah al Mustafidl fi 'ilm al Tajwid. Kedua memberikan indikasi kuat berafilisasi madzhab qira'at 'Ashim riwayat Hafsh sekalipun tidak disebutkan redaksi tegas, kitab yang tergolong Fathurrahman fii tajwid al Qur'an. Ketiga kitab tidak memberikan indikasi beafilisasi pada madzhab apapun. Kategori ketiga ini ada dua macam yakni : Tidak diafilisasikan karena untuk konsumsi anak-anak dimana kitab yang dimaksud adalah Hidayah al Syibyan fii Tajwid al Qur'an dan Tuhfathul Athfal. Selanjutnya tidak diafilisasi karena membahas kaidah kaidah tajwid yang bersifat universal, kitab ini adalah Matn al Jazariyah.

\section{2. "De Yure" Qira'at 'Ashim riwayat Hafsh di Nusantara}

Dalam analisis ini, terdapat dua sanad milik ulama Nusantara yang tergolong paling tua usiannya dimulai abad ke-20, yakni milik KH. Muhammad Moenawir (Yogyakarta) dan KH. Muhammad Munawwar (Gresik). Berikut akan dipaparkan mengenai bigrofi dan analisis terhadap sanad beliau:

a. Profil KH. Muhammad Moenawir

Beliau adalah Muhammad Moenawir bin KH. 'Abdullah Rasyad bin KH. Hasan Bashari (Kasan Besari). Putra Kedua dari pasangan KH. 'Abdullah Rasyad dan Ibu Khadijah. Belajar kepada KH. Khalil (Bangkalan), beliau juga belajar kepada KH. ‘Abdullah (Bantul), KH. Shalih (Semarang), KH. 'Abdurrahman (Magelang).

Pada tahun 1888, beliau memutuskan untuk meneruskan pendidikan studinya ke Makkah al Mukarromah dan Madinah al Munawwarah. Di Makkah, beliau berkonsentrasi pada ilmu bidang Al Qur'an dengan berguru kepada : Syaikh 'Abdullah Sunqoro, Syaikh Sarbini, Syaikh 'Abdus Syakur, Syaikh Manshur, Syaikh Ibrahim Huzaimiy, Syaikh Muqriy, Syaikh Yusuf Hajar. Sdangkan selama di Madinah selam 5 tahun beliau mempelajari ilmu tauhid, ilmu fiqh, bahasa, dll. Selain mampu menghafal Al Qur'an secara sempurna, beliau juga menguasai ilmu qira'ah sab'ah dengan baik serta mendapatkan riwayat sanad yang bersambung sampai kepada Rasulullah. Sanad Qira'at beliau merupakan riwayat Qira'at 'Ashim riwayat Hafsh thariq 'Ubaid bin al Shabbah.

Pada tahun 1909, beliau membuka sebuah pengajian al Quran di surau kecil miliknya yang terdapat di daerah Kauman-Yogyakarta. Pada akhir tahun 1909, beliau akhirnya memutuskan untuk mendirikan sebuah pesantren di Krapyak. Di pesantren inilah, beliau mengajarkan pengetahuan agama ynag dimiliki teristimewa pada bidang al Qur'an. Setelah 33 tahun pesantren tersebut berdiri, beliau telah mencetak kader-kader yang siap 
meneruskan mata rantai sanad qira'at yang beliau miliki. Di antaranya adalah : $\mathrm{KH}$. Muhammad Arwani Amin (Kudus), KH. Badawi (Kaliwungu), KH. Zuhdi (Nganjuk), KH. 'Umar (Solo), KH. 'Umar (Cirebon), KH. Muntaha (Kalibeber-Wonosobo), KH. Syathibiy (Kutoarjo), KH. Hasbullah (Wonokromo-Yogyakarta), KH. Muhyiddin (JejeranYogyakarta), KH. Aminuddin (Kroya).Di antara murid beliau tersebut, yang paling terkenal memberikan sanad Al Qur'an adalah : KH. Muhammad Arwani Amin (Kudus), KH. Badawi (Kaliwungu), KH. 'Umar (Mangkuyudan-Solo).KH. Muhammad Moenawir wafat pada tanggal 06 Juli 1942/11 Jumadil Akhir 1360.

b. Profil KH. Munawwar (Gresik)

Beliau adalah Munawwar bin H. Nur, menurut garis geneologi beliau masih termasuk keturunan Prabu Brawijaya V. Beliau lahir pada tahun 1884 dan wafat pada tahun 1994 bertepatan dengan tanggal 03 Ramadlan 1365 H, pada usia 60 tahun. Dalam lembaran sanad beliau, diketahui bahwa beliau merupakan adik seperguruan KH. Muhammad Moenawir.Menurut KH. Badawi 'Abdurrasyid (Kaliwungu), menyebutkan bahwa ada tiga pelajar yang belajar ilmu qira'at kepada Syaikh 'Abdul Karim bin 'Umar al Badri al Dimyathi yakni: Muhammad Moenawir (Yogyakarta), Munawwar (Gresik), Badawi (Kaliwungu) yang mendapatkan qira'at riwayat 'Ashim riwayat Hafsh.

c. Analisis dan Kritik Sanad Moenauwir dan Munawwar

Dapat disimpulkanlembar sanad KH. Moenauwir dan KH. Munawwar keduanya memiliki kesamaan,baik dari sisi jumlah mata rantai maupun redaksi yang digunakan. Kalaupun terjadi perbedaan mungkin hanya secara redaksional saja dan tidak menyentuh esensialnya.Dari segi penyebutan rawi misalnya, ada lima perbedaan diantaranya:

a) Pada mata rantai ke-1 KH. Moenawir disebutkan Syafi'una wa Nabiyyuna Muhammad Rasulullah SAW, dalam KH. Munawwar disebutkan Sayyidina Muhammad SAW.

b) Pada mata rantau ke-4 KH. Moenawir tidak disebutkan al Kuffi yang dalam KH. Munawwar disebutkan.

c) Pada mata rantai ke-13 KH. Moenawir disebutkan al asynani dengan huruf syin dalam KH. Munawwar disebut dengan huruf sin.

d) Pada mata rantai ke-24 KH. Moenawir tidak disebutkan al Azmiriy yang dalam KH. Munawwar disebutkan.

Dalam masalah redaksi penyebutan gelar, hanya ada dua perbedan dalam dua mata rantai tersebut, yakni:

a) Pada mata rantai ke-16 KH. Moenawir disebutkan Syaikh al Imam dalam KH. Munawwar disebutkan dengan al Imam. 
b) Pada mata rantai ke-17 KH. Moenawir disebutkan dengan kata al Syaikh dan dalam KH. Munawwar dengan al Imam.

Dari beberapa perbedaan redaksional yang sama sekali tidak menyentuh permasalahan esensial tersebut dapat disimpulkan bahwa kedua orang ulama tersebut memang mendapatkan sanad dari seorang guru yang sama. Dari kedua sanad qira'at tersebut juga dapat diketahui bahwa kedua ulama Nusantara tersebut sama-sama menempati mata rantai sanad ke-28.

\section{Qira'at 'Ashim riwayat Hafsh: sosok dan teori qira'at}

\section{Profil imam 'Ashim}

Beliau adalah 'Ashim bin Bahdalah - maula Bani Judzaimah - bin Malik bin Nashr bin Qa'in bin Asad. Nama kuniyah yang beliau miliki adalah Abu Bakar. Ada juga yang mengatakan bahwa nama beliau adalah 'Ashim bin Abi al-Najud al-Asadi al-Kufi. Beliau mendapatkan posisi terhormat di kalangan para ulama ahli qira'at. Diantara pujian yang dialamatkan kepada beliau berasal dari Abu Ishaq As-Subai'i yang telah menganggap beliau sebagai seorang ulama paling ahli dalam bidang qira'at al-Qur'an. Kemudian menurut Syamr bin 'Athgiyah, Imam 'Ashim adalah orang yang paling menguasai qira'at Zaid bin Tsabit.

'Ashim Bahladah bukan hanya ulama yang ahli dalam bidang ilmu qira'at. Beliau juga termasuk dalam jajaran tokoh ahli hadis, menguasai ilmu bahasa (ahli ilmu nahwu dan logat yang fashih), apabila melontarkan statment, maka statmentnya akan masyhur di kalangan masyarakat. 'Ashim adalah seseorang yang tekun dalam mengerjakan ibadah, memiliki etika yang terpuji, dan memiliki suara yang sangat indah. Imam 'Ashim meninggal dunia di Kufah pada atahun 127/744. Ada juga pendapat yang mengatakan bahwa beliau meninggal pada tahun $128 / 745$

Guru dalam bidang qira'at, tercatat ada dua nama tokoh yang menjadi syaikh Imam 'Ashim. Pertama, Abu 'Abdirrahman al-Sulami adalah orang yang pertama kali mengajarkan al-Qur'an di Kuffah setelah 'Utsman bin 'Affan mengirimkan kopi mushaf kekawasan tersebut. Imam 'Ashim sudah belajar semenjak masih usia kanak-kanak dan belum mencapai usia akil baligh kepada Abu 'Abdirahman. Qira'at yang beliau pelajari dari Abu 'Abdirahman adalah riwayat yang berasal dari 'Ali bin Abi Thalib ra. 'Ashim menegaskan bahwa tidak ada satu pun perbedaan antara riwayat yang dia sampaikan dengan pelajaran yang telah diperoleh dari Abu 'Abdirahman. Begitu juga bahwa riwayat yang disampainkan oleh Abu 'Abdirrahman tidak ada satu pun yang berbeda dengan pelajaran yang telah dia terima dari 'Ali bin Abi Thalib. Kedua, Zirr ibn Hubaisy adalah -- salah seorang dari Bani Ghadhirah - bin Malin bin Tsa'labah bin 
Khuzaimah. Ziir bin Hubaisy mengajarakan riwayat qira'at kepada 'Ashim yang berasal dari 'Abdullah bin Mas’ud. Menurut Imam ‘Ashim, Zirr bin Hubaisy merupakan orang yang sangat fashih dalam berbahasa Arab.

Murid di dalam menyampaikan qira'at, 'Ashim mengaku telah memberikan jalur sanad qira'at yang berbeda kepada kedua orang murid yang menjadi perawi madzhab qira'atnya. Qia'at yang dia ajarkan kepada Hafsh adalah riwayat yang bersal dari Abu 'Abdirrahman alSulami, dari 'Ali bin Abi Thalib ra. Sedangkan qira'at yang diajarkan kepada Abu Bakar Syu'bah bin 'Ayyasy adalah yang beliau pelajari dari Zirr bin Hubaisy dari Ibnu Mas'ud ra.

\section{Profil Imam Hafsh}

Beliau adalah Abu 'Umar Hafsh bin Sulaiman bin al-Mughirah al-Asadi al-Bazzar alGhadhiri al-Kufi. Ada juga yang menyebutkan bahwa garis nasab beliau adalah Hafsh bin Abi Dawud (nama kuniyah ayahanda Hafsh). Belia juga dikenal dengan sebutan nama Hufaish. Menurut Khalaf bin Hisyam, beliau lahir pada tahun $90 \mathrm{H}$. Hafsh sebenarnya merupakan putra tiri Imam 'Ashim. Menurut Ayyub bin Mutawakkil, kualitas riwayat qira'at yang dimiliki oleh Hafsh dianggap lebih shahih dibandingkan dengan riwayat qira'at Abu Bakar Syu'bah bin 'Ayyasy. Hal ini sangat wajar, karena Hafsh memang tinggal serumah dengan sang ayah tiri dan belajar dari Imam 'Ashim seperti anak kecil yang belajar dari orang tuanya. Hafsh bin Sulaiman juga memiliki karir politik yang cukup cemerlang. Dalam hal ini dia sempat menjabat Hakim Agung (Qadhi) kawasan Kuffah. Beliau meninggal dunia pada usia 90 tahun, tepatnya pada tahun $180 / 796$.

Guru dalam bidang qira'at, Hafsh disebut-sebut hanya belajar kepada ayah tirinya, yakni 'Ashim bin Abi al-Najud. Sedangkan murid yang meriwayatkan qira'at dari beliau cukup banyak, di antaranya adalah 'Ubaid bin al-Shabbah, 'Amr bin Ash-Shabbah, Husain bin Muhammad al-Marwadzi, Hamzah bin al-Qasim al-Ahwal, Sulaiman bin Dawud al-Zahrani, Hamdan bin Abi 'Utsman al-Daqqaq, al-'Abbas bin al-Fadhl Ash-Shigar, 'Abdurahman bin Muhammad bin Waqid, Muhammad bin al-Fadhl, Khalaf al-Haddad, Hubairah bin Muhammad bin Tammar, Abu Syu'aib al-Qawwas, al-Fadhl bin Yahya bin Syahi bin Firas al-Anbari, Husain bin 'Ali al-Ju'fi, Ahmad bin Jubair al-Anthaki, dan Sulaiman al-Faqimi.

\section{Thariq Asy-Syathibiyah}

Thariq adalah mata rantai silsilah qira'at yang berada di bawa perawi. Dengan kata lain, tokoh di dalam thariq adalah murid-murid yang belajar ilmu qira'at dari para perwai. Untuk qira'at 'Ashim riwayat Hafsh sendiri dikenal memiliki dua macam thariq, yakni thariq AsySyathibyyah dan thariq al-Thayyibah. Yang dimaksud thariq Asy-Syathibyyah adalah qira'at yang didasarkan pada jalur periwayatan yang terdapat dalam kitab Hirzul-Amani karya Asy- 
Syathibi. Sedangkan yang dimaksud dengan thariq al-Thayyibah adalah qira'at yang didasarkan pada jalur periwayatan yang terdapat dalam kitab Thayyibah al-Nasr karya Ibn alJazari. Pada thariq Asy-Syatibiyyah, disebutkan bahwa setiap imam memiliki dua orang perawi, setiap perawi memilki seorang thariq, dan setiap thariq memiliki satu thariq lagi di bawahnya. Sementara thariq al-Thayyibah memiliki dua orang thariq pada setiap perawi, dan setiap thariq juga memiliki dua thariq dibawahnya lagi. Karena di dalam thariq AsySyatibiyyah hanya ada satu thariq, maka syaikh qira'at yang berada di bawah perawi Hafsh adalah 'Ubaid bin al-Shabbah. Sedangkan syaikh qira'at di bawah perawi Hafsh yang terdapat dalam thariq al-Thayyibah adalah 'Ubaid bin Ash-Shabah dan 'Amr bin Ash-Shabbah.

Di antara perbedaan yang sangat mencolok di antara kedua thariq tersebut adalah cara baca madd ja'iz munfashil. Menurut thariq 'Ubaid bin Ash-Shabbah (thariq Asy-Syathibiyyah), kadar harakat madd ja'iz munfashil adalah empat harakat atau dua alif. Sementara tahariq 'Amr bin Ash-Shabbah hanya membaca seukuran dua harakat atau satu alif. Dengan demikian thariq al-Thayyibah bisa membaca madd ja'izi munfashil dengna kadar dua harakat atau empat harakat. Perlu diketahui bahwasanya, qira'at 'Ashim riwayat Hafsh yang menjadi bacaan alQur'an kaum muslimin di Indonesia adalah thariq yang mengikuti thariq Asy-Syathibiyyah.

\section{Teori Qiraat 'Ashim Riwayat Hafs thariq asy-Syathibiyah}

Berikut ini disampaikan beberapa teori madzhab qiraat 'Ashim riwayat Hafsh thariq Syatibiyah, diantara sebagai berikut:

a. Bacaan basmalah

Mengenai aturan membaca basmalah, pada pembacaan basmalah yang dibaca diantara dua surah al-Qur'an para imam qiraat berbeda pendapat. Di antara mereka ada yang berpendapat bahwa basmalah tetap dibaca diakhir sebuah surah sebelum seseorang melanjutkan pada surah yang berikutnya. Namun ada juga imam qiraat yang berpendapat bahwa basmalah tidak perlu lagi dibaca di antara dua surah. Diantara kelompok imam yang berpendapat bahwa basmalah dibaca diantara dua surah adalah imam 'Ashim.

b. Ghunnah

Posisi Imam 'Ashim sama dengan para imam qira' at dalam membagi bacaan ghunnah.

c. Idgham

Pembahasan idgham dibagi menjadi dua kelompok besar:

1) Idgham kabir, yakni bertemunya dua huruf mutamatsilan, mutaqariban, atau mutajanisan yang sama-sama berharakat dalam satu kata atau dua kata. Dalam kasus idgham kabir, hanya ada idgham kabir mutamasilan dalam riwayat Hafsh, sedangkan idgham kabir mutaqariban maupun mutajanisan tidak ada. 
2) Idgham shaghir, yakni bertemunya dua huruf mutamasilan, mutaqariban, atau mutajanisan dalam satu kata atau dua kata, dimana huruf pertama disukun dan huruf yang kedua berharakat. Segmen ini dibagimenjadi tiga: yakni 1) idgham mutamasilan,yakni bertemunya dua huruf yang memiliki kesamaan makhraj dan sifat. Selain dibaca idgham mutamasilan, Hafs juga membacanya saktah. 2) idgham mutajanisan, yakni bertemunya dua huruf yang memiliki kesamaan makhraj namun tidak memiliki kesamaan sifat. Qs. 11:412. Riwayat Hafs tahriq asy-Syatibiyah mengidghamkan lafal irkab pada kata ma'ana.3) idgham mutaqarriban, yakni bertemunya dua huruf yang memiliki kedekatan makhraj dan sifat. Qs. 83:14. Riwayat Hafs thariq Syathibiyah tidak mengidghamkan lafal bal pada kata rana, melainkan membacanya saktah.

d. Ha' dhamir

Ha' dhamir yang terletak diantara dua huruf berharakat. Qiraat jenis ini ada dua pendapat mengenai cara membacanya, ada yang boleh dibaca dengan madd, dan ada yang mengatakan tidak dibaca madd.Hafs secara umum membaca dua harakat ha' dhamir jenis ini. Dan ha'dhamir yang terletak sebelum huruf sakinah dan setelahnya adalah huruf berharakat, secara umum Hafs tidak membacanya madd ha' dhamir jenis ini, kecuali pada ayat.

e. Tafkhim dan tarqiq

Yang dimaksud dengan tafkhim adalah bentuk artikulasi huruf secara tebal yang mendekati vokal /o/. Sementara yang dimaksud dengan tarqiq adalah bentuk artikulasi huruf yang tipis yang mendekati vokal /i/. Mengenai masalah artikulasi tafkhim dan tarqiq, posisi Imam Ashim berposisi sama denganimam qira'at yang lainnya.

f. Hamzah washl dan Hamzah Qath

Pada pembahasan posisi hamzah qath' dalam menghilangkan hamzah washl dan tetap membaca fathah hamzah qath ada tujuh buah lafal tipe ini yang terdapat di dalam mushaf alQur'an. Para imam qira'at sepakat untuk menghilangkan hamzah washl pada lima tempat (Qs. 2:80, Qs. 34:8, Qs. 38:75, Qs. 63:6, Qs. 37:153) \&(Qs. 19:78, Qs. 38:63). Untuk riwayat Hafs, ketujuh lafal tersebut dibaca dengan menghilangkan hamzah washl.

g. Saktah

Dalam permasalahan saktah, pendapat para imam qira'at bisa dibilang cukup variatif. Untuk riwayat Hafs thariq syatibiyah, ada empat bacaan saktah dalam mushaf yang tidak dibaca oleh riwayat dan thariq qira'at lainnya. keempat bacaan saktah yang dimaksud adalah berhenti antara lafal iwaja dan qayyima yang terdapat dalam Qs. 18:1-2, Qs. 36:52, Qs. 75:27, Qs. $83: 14$. 
Disamping pada empat tempat tersebut, riwayat Hafs thariq asy-Syatibiyah juga memiliki bacaan saktah yang dibaca juga oleh qira'at melalui jalur riwayat yang lain. Bacaan saktah tersebut terletak pada dua tempat, yakni pada akhir surah al-Anfal dengan surah at-Taubah dan saktah yang di baca antara lafal maliyah dan halaka pada Qs. 69:28-29.

h. Ya' idhafah dan Ya' Za'idah.

1) Menurut para imam qira'at terdapat 212 ya' idhafah di dalam mushaf al-Qur'an. Para imam qira'at telah membedakan posisi ya' idhafah pada sebuah kata menjadi enam macam:

a) Terdapat sebelum huruf hamzah yang berharakat fathah. Ada 99 ya'idhafah jenis ini. Dan secara umum Hafs membacanya sukun.

b) Terdapat sebelum huruf hamzah yang berharakat kasrah. Jenis ya' idhafah ini terdapat di 52 tempat. Hampir keseluruhan ya' jenis ini dibaca kasrah oleh Hafs, kecuali pada 11 tempat.

c) Terdapat sebelum huruf hamzah yang berharakat dhammah. Ya'idhafah jenis terdapat di 10 tempat. Riwayat Hafs membaca semuanya sukun.

d) Terdapat sebelum /al/ al-ta'rif. Ya' idhafah jenis ini terdapat di 14 tempat. Hampir semuanya dibaca fathah oleh Hafs, kecuali di satu tempat, yakni pada Qs. 21:105.

e) Terdapat sebelum hamzah washl. Jenis ini terdapat di 7 tempat dan kesemuanya dibaca sukun oleh Hafs.

f) Terdapat sebelum huruf hijaiyah selain hamzah qath maupun hamzah washl. Jenis ini terdapat di 30 tempat. Dalam hal ini, 20 lafal dibaca fathah oleh Hafs, ada satu yang dibaca dengan membuang huruf ya', dan satu lagi dibaca fathah oleh imam 'Ashim. Adapun selebihnya, maka dibaca sukun.

Dengan demikian, dari 212 ya' idhafah yang ada dalam mushaf, 47 diantaranya dibaca fathah oleh Hafs, satu dibaca hadzf oleh Hafs, dan satu lagi dibaca fathah oleh 'Ashim, sedangkan 163 yang lainnya dibaca sukun.

2) Ya' Zaidah, menurut para imam qiraat ada 62 ya' Zaidah yang terdapat di dalam mushaf al-Qur'an. Hampir seluruhnya dibaca hafdz(membuang ya'zaidah) oleh Hafs. Hanya satu saja yang dibaca itsbat (tidak membuang ya') dengan harakat fathah ketika washl, boleh dibaca hadzf atau itsbat. Terdapat pada Qs. 27:36.

i. Madd

Para imam qira'at membagi pembahasan madd menjadi dua kelompok besar:

a. Madd ashli atau madd thabi'i. Dibagi lagi menjadi dua, yakni madd thabi'i kilmi dan madd thabi'i harfi. 
b. Madd Far'i. Dibagi lagi menjadi dua macam, yakni Pertama, madd yang disebabkan oleh huruf hamzah, madd jenis ini dibagi lagi menjadi tiga, yakni a) madd wajib muttasil, riwayat Hafs thariq asy-syatibiyah membacanya sepanjang 4/5 harakat baik washl atau waqaf, b) madd ja'iz munfashil, riwayat Hafs thariq asy-Syatibiyah membacanya sepanjang 4/5 harakat, dan c) madd badal, imam Ashim membacanya seukuran 2 harakat. Kedua, madd yang disebabkan oleh sukun. Jenis ini dibagi menjadi tiga, yakni a) madd lazim,imam 'Ashim membacanya 6 harakat, di dalam segmen ini dibagi lagi menjadi dua macam yaitu : madd lazim kilmi, madd lazim harfi. b) madd 'aridh, Imam Ashim membacanya 2,4, atau 6 harakatc) madd lin, Imam Ashim membacanya sepanjang 2 harakat.

\section{PENUTUP}

\section{Kesimpulan}

Perkembangan madzhab qira'at 'Ashim riwayat Hafsh secara definitif di bumi Nusantara baru dimulai pada abad ke-20. Hal ini ditandai dengan keberadaan sanad qira'at milik ulama Nusantara, dalam hal ini sanad milik KH. Muhammad Moenauwir dan KH. Munawwar. Keduanya baru berhasil memboyong sanad qira'at tersebut dari Makkah al-Mukarramah pada tahun 1909 dan tahun 1920. Namun demikian bacaan al-Qur'an penduduk Nusantara sejak masa awal datangnya Islam bisa di pastikan berafiliasi pada madzhab qira'at 'Ashim riwayat Hafsh. Hal ini bisa dibuktikan melalui beberapa kesamaan qawa'id ushuliyyah maupun farsy al-huruf qira'at al-Qur'an penduduk Nusantara dengan teori-teori qira' at yang terdapat dalam madzhab qira' at 'Ashim riwayat Hafsh.

Bukti yang lainnya adalah adanya kesamaan antara madzhab qira'at penduduk Nusantara dengan madzhab qira'at para ulama pembawa Islam ke kawasan Nusantara. hal ini juga diperkuat dengan kesamaan metode pembelajaran dan kurikulum baca al-Qur'an dalam kurikulum pendidikan Islam di Nusantara yang menggunakan metode di salah satu negeri asal ulama pembawa Islam di Nusantara, yakni metode qawa'id Baghdadiyyah. Begitu juga dengan keberadaan kitab-kitab tajwid dalam kurikulum pendidikan Islam di Nusantara yang berafiliasi pada madzhab qira'at 'Ashim riwayat Hafsh, semua itu membuktikan bahwa secara de facto, penduduk Nusantara telah menganut madzhab qira' at 'Ashim riwayat Hafsh sejak masa kedatangan Islam di kawasan tersebut. Hanya saja secara de yure, sejarah perkembangan ilmu qira'at di Nusantara baru muncul pada abad ke-20.

\section{DAFTAR PUSTAKA}


Amira Rasheeda Azman, 2014, Perbandingan Manhaj Riwayat Kholaf dan Kholad, Darul Quran.

Abu Bakar Fahmi, 2013. Perbezaan Riwayat Qiraat Qolun dan Warsy, MTQN Perak.

Al-Asfahani al-Allamah al-Raghib, 1997, Mufradat Alfaz Al-Quran, Tahqiq: Safuan Adnan Dawudi. Beirut: Dar al-Qalam, Damsyik: Dar al-Syamiyyah.

Al-Shaukani, Imam Muhammad Ibnu Ali bin Muhammad, (1414H/1994M), Irsyad al-Fuhul, Beirut: Dar al-Kutub al-Ilmiyyah.

Amira Rasheeda Azman, 2014, Perbandingan Manhaj Riwayat Kholaf dan Kholad, Darul Quran.

Al-Zarkasyi, al-Imam Badr al-Din Muhammad Ibnu Abdullah, (1408/1988), al-Burhan fi Ulum Al-Quran. Beirut, Dar al-Jail.

Al-Bukhari, Abu Abdullah Muhammad Ibn Ismail, (t.t), Sahih al-Bukhari, jil. 2, juz. 3 kitab 38, bab 4. (t.t.p), Dar al-Ihyaa al-Kutub al-Arabiyyah.

Abdul Ghafur Mahmud Mustafa Ja far, (1417/1996), Al-Quranwa al-Qiraat Sab"eah al-Haqiqah alAlaqah Sihhah al-Naql. Al-Qaherah, Jamie ah al-Azhar. 